\section{Editor}

Patricia Casey (Ireland)

\begin{tabular}{|c|c|c|}
\hline Editorial Board & Helen Killaspy (UK) & Trainee Editor \\
\hline Gwen Adshead (UK) & Simon Kyaga & Yasmin Al-Asady \\
\hline Mary-Jane Attenburrow & (Sweden) & (UK) \\
\hline & Jason Luty (UK) & Editorial Assistant \\
\hline Kamaldeep Bhui (UK) & Sean Lynch (UK) & Jonica Thomas \\
\hline Guy Brookes (UK) & Jair Mari (Brazil) & \\
\hline John Cookson (UK) & Femi Oyebode (UK) & Staff Editors \\
\hline Gian Maria Galeazzi (Italy) & Jan Scott (UK) & Kasia Krawczyk \\
\hline Roger Ho (Singapore) & Katharine Smith (UK) & Maddock \\
\hline Malcolm Hopwood & Jessica Yakeley (UK) & Katherine Sole \\
\hline (Australia) & David Yeomans (UK) & \\
\hline Julian Hughes (UK) & Rodolfo Zaratiegui & \\
\hline Sarah Huline-Dickens (UK) & (Argentina) & \\
\hline
\end{tabular}

\section{Subscriptions}

Advances Volume 20, 2014 (six issues)

(full airmail £19/US\$34 extra)

\begin{tabular}{|c|c|c|c|}
\hline & $\begin{array}{l}\text { Members of the } \\
\text { Royal College } \\
\text { of Psychiatrists }\end{array}$ & Non-members & Institutions \\
\hline \multicolumn{4}{|c|}{ Print (+ free online) } \\
\hline Europe (\& UK) & f55 & £156 & $£ 167$ \\
\hline USA & US\$103 & US\$244 & US\$289 \\
\hline Elsewhere & £65 & £166 & £181 \\
\hline \multicolumn{4}{|l|}{ Online (only) } \\
\hline Worldwide & Free & f122/US\$174 & f154/US\$237 \\
\hline
\end{tabular}

Payment may be made by cheque/money order, by Access/Master Card/ Visa/American Express, or by UNESCO coupons. EC subscribers: please supply your Member State Code and Value Added Tax (VAT) number.

Payment should be made to Maney Publishing, Suite 1C, Joseph's Well, Hanover Walk, Leeds LS3 1AB, UK (tel: +44 (0)113 243 2800; fax: +44 (0)113 386 8178; email: subscriptions@maney.co.uk). For subscriptions in North America, please contact Maney Publishing, Two Penn Center Plaza, Suite 200, Philadelphia PA 19102, USA (tel: 1 (215) 854 6402; fax: 1 (215) 569 0216; email: northamerica@maneypublishing.com). Continuing professional development (CPD) Those wishing to register for $\mathrm{CPD}$ with the Royal College of Psychiatrists should contact the CPD unit (tel: +44 (0)20 37012621 or +44 (0)20 3701 2610). There is no charge for participation in the CPD scheme for Members, Fellows and Affiliates of the College.

CPD Online The College also publishes an interactive online learning facility for CPD in psychiatry. Further details, sample modules and subscription information can be viewed at www.psychiatrycpd.org. Discounts are available for Advances subscribers.

Correspondence Letters submitted for publication should be emailed to Professor Patricia Casey at apt@rcpsych.ac.uk or posted to Advances in Psychiatric Treatment, Royal College of Psychiatrists, 21 Prescot Street, London E1 8BB, UK.

Printed by Henry Ling Ltd, 23 High East Street, Dorchester, Dorset DT1 1 HD.

(C) The Royal College of Psychiatrists 2014. Published by the Royal College of Psychiatrists, a charity registered in England and Wales (228636) and in Scotland (SC038369). Unless so stated, material in Advances in Psychiatric Treatment does not necessarily reflect the views of the Editor or the Royal College of Psychiatrists. The publishers are not responsible for any errors of omission or fact.

The College crest is a registered trade mark of the Royal College of Psychiatrists.

ISSN 1355-5146

\title{
New from CPD Online
}

\section{CPD ONLINE}

CPD Online is an e-learning resource offered by the Royal College of Psychiatrists. The website contains a range of learning modules and podcasts that provide a flexible, interactive way of keeping up to date with progress in mental health. College members may use CPD Online for up to $25 \mathrm{CPD}$ points in the UK. Access to the modules is through annual subscription, but we offer a series of free trial modules. For more information, visit the CPD Online website: www.psychiatrycpd.org.

\section{Recent modules and podcasts}

\section{Managing the adverse effects of clozapine}

NICE (2009) recommends clozapine for use in schizophrenia if two previous antipsychotics have been ineffective. Clozapine improves outcomes in around $50-60 \%$ of these cases, but concerns over adverse effects can cause a premature withdrawal of this highly effective treatment. This module aims to improve understanding of the adverse effects that may arise with clozapine use, increase confidence in alleviating them and suggest management strategies. CPD Credits: 1

\section{Transferring care between age-specific services: young people's transitions}

The healthcare transitions faced by young people with mental health problems and disorders can be extremely challenging, and the importance of managing these transitions well has been acknowledged nationally and internationally. This module describes different types of transition and models of transitional care, summarises principles of good practice and uses case studies to facilitate reflection on how personal clinical practice and service development might be improved. CPD Credits: 1

\section{Podcast Medically unexplained symptoms}

Medically unexplained symptoms can be extremely distressing and debilitating for patients, but they are often difficult to treat. Dr Raj Persaud talks to Dr Richard Brown about his 'integrative cognitive model' of medically unexplained symptoms, and discusses the practical implications regarding treatment. CPD Credits: 0.5

\section{Podcast Psychology of optimism}

Dr Raj Persaud discusses the meaning and underlying psychological constructs of optimism with Dr Rebecca McGuire-Snieckus, author of the paper 'Hope, optimism and delusion' published in the Psychiatric Bulletin. CPD Credits: 0.5
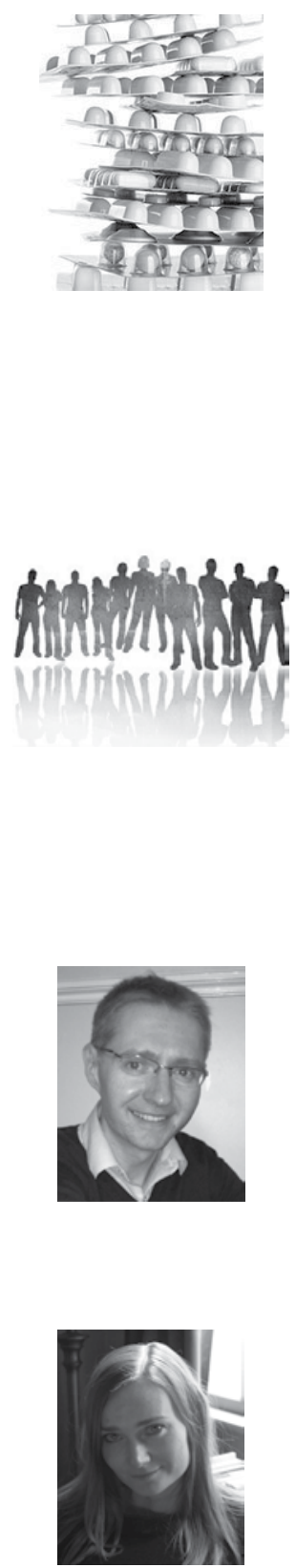